\title{
PENGARUH PENAMBAHAN IOTA KARAGINAN PADA EKSTRAKSI AGAROSA DARI AGAR-AGAR MENGGUNAKAN CETYL PIRIDINIUM KLORIDA
}

\author{
Subaryono*), B.S.B. Utomo*), T. Wikanta") dan N. Satriyana")
}

\begin{abstract}
ABSTRAK
Penelitian pemurnian agarosa dari agar-agar menggunakan cetyl piridinium klorida dengan penambahan iota karaginan telah dilakukan. Faktor yang diteliti adalah besarnya penambahan iota karaginan yang digunakan dalam proses tersebut $0 \% ; 0,5 \% ; 1 \% ; 1,5 \%$ dari bobot rumput laut kering) terhadap kualitas agarosa yang dihasilkan. Parameter yang diamati meliputi rendemen agarosa, kadar air, kadar sulfat, kadar 3,6-anhidro-galaktosa, kekuatan gel, suhu pembentukan gel, dan suhu pelelehan gel. Hasil penelitian menunjukkan bahwa konsentrasi iota karaginan yang paling baik digunakan pada proses tersebut adalah $1 \%$, yang menghasilkan agarosa dengan kadar sulfat sebesar $0,59 \%$ dan kekuatan gel sebesar $188,14 \mathrm{~g} / \mathrm{cm}^{2}$. Perlakuan tersebut tidak memberikan pengaruh yang nyata terhadap rendemen, kadar air, kadar 3,6-anhidro-galaktosa, suhu pembentukan gel dan suhu pelelehan gelnya.
\end{abstract}

ABSTRACT: Research on the extraction of agarose from agar using cetyl pyridinium chloride with the addition of iota carrageenan. By: Subaryono, B.S.B. Utomo, T. Wikanta and N. Satriyana

\begin{abstract}
Research on the extraction of agarose from agar using cetyl pyridinium chloride with the addition of iota carrageenan was carried out. lota carrageenan at concentrations of $0,0.5,1$ and $1.5 \%$ based on dry seaweed weight was used in this experiment. Yield, moisture, sulphate and 3.6-anhydro-galactose contents, gel strength, gelling point as well as melting point were observed as quality parameters of the product. Research result showed that the best concentration of iota carrageenan was $1 \%$, which gave product with $0.59 \%$ sulphate content and $188.14 \mathrm{~g} / \mathrm{cm}^{2} \mathrm{gel}$ strength. The treatments had no effect on yield, water content, 3.6-anhydro-galactose content, gelling point and melting point.
\end{abstract}

KEYWORDS: agarosa, cetyl pyridinium chloride, iota carrageenan, extraction process

\section{PENDAHULUAN}

Agarosa merupakan suatu fraksi dari agar-agar yang merupakan polimer netral dan sedikit mengandung sulfat. Agarosa dikenal sebagai fraksi pembentuk gel dari agar-agar, dimana sifat-sifat gel yang dihasilkannya mendekati sifat-sifat gel ideal untuk keperluan bidang bioteknologi. Selain itu, agarosa sebagai produk proses hilir dari agar-agar memiliki harga jual yang lebih tinggi dibandingkan dengan produk-produk isolasi rumput laut lainnya. Harga jual agarosa di pasaran internasional adalah sebesar $\$ 1.000-5.000 / \mathrm{kg}$, dengan spesifikasi kadar sulfat $0,1-0,35 \%$ dan gel strength $\geq 500 \mathrm{~g} / \mathrm{cm}^{2}$ (SigmaAldrich, 2002-2003).

Penggunaan agarosa yang begitu luas dalam bidang bioteknologi sejalan dengan usaha-usaha pengembangan bidang tersebut. Peningkatan kebutuhan agarosa diantisipasi dengan mengembangkan teknik yang tepat dan efisien untuk mengisolasi agarosa dari agar-agar. Beberapa metode yang telah dikembangkan di negara-negara maju, antara lain metode cetyl piridinium klorida (CPC Method), metode DEAE-Cellulose dan metode Polyethylen Glycol (PEG Method).

Agarosa dengan kualitas baik ditentukan oleh kandungan sulfat dari agarosa tersebut. Kadar sulfat agarosa terdapat dalam jumlah yang sangat kecil (Selby dan Wyne, 1973). Kadar sulfat agarosa berkisar antara 0,03-0,04\% (Chapman dan Chapman, 1980). Agarosa yang umum di pasaran memiliki kandungan sulfat antara $0,1-0,35 \%$, sedangkan agarosa dengan kadar sulfat $\leq 0,05 \%$ tidak tersedia secara luas karena harganya sangat mahal (Sigma-Aldrich, 20022003).

Metode cetyl piridinium klorida (CPC method) merupakan salah satu metode ekstraksi agarosa yang relatif mudah dilakukan. Selain itu, metode isolasi agarosa dengan cetyl piridinium klorida (CPC

\footnotetext{
Peneliti pada Pusat Riset Pengolahan Produk dan Sosial Ekonomi Kelautan dan Perikanan

') Mahasiswa S1 Institut Pertanian Bogor
} 
method) ini mampu menghasilkan agarosa dengan kandungan sulfat yang cukup rendah. Hjerten (1962), mengemukakan bahwa cetyl piridinium klorida merupakan senyawa amonium kuarterner yang mempunyai kemampuan untuk mengendapkan agaropektin yang merupakan polisakarida sulfat dari agar-agar. Cetyl piridinium klorida juga merupakan suatu polimer kationik yang akan bereaksi dengan kandungan ion sulfat yang tinggi dari agar-agar. Penambahan karaginan pada metode ini untuk memperbesar ukuran dari endapan sulfat yang terbentuk sehingga memudahkan dalam proses pemisahan. Penggunaan iota karaginan dilakukan karena iota karaginan dapat membentuk dispersi thixotropic sehingga mempunyai sifat pensuspensi yang lebih baik. Dengan demikian iota karaginan yang terdispersi merata dalam sol agar-agar akan mengikat iota karaginan yang lebih banyak (Moirano, 1977). Mengingat banyaknya sumber iota karaginan di dalam negeri dan teknik ekstraksinya yang sudah dikuasai, maka perlu dicoba penelitian ekstraksi agarosa dengan penambahan iota karaginan tersebut untuk menghasilkan agarosa dengan kualitas yang baik. Dengan keberhasilan penelitian ini diharapkan dapat memberikan nilai tambah terhadap produk agar-agar.

\section{BAHAN DAN METODE}

Bahan yang digunakan untuk proses ekstraksi agarosa dalam penelitian ini adalah rumput laut merah jenis Glacilaria chilensis hasil budidaya PT. OHAMA di Lampung. Sedangkan bahan kimia yang digunakan untuk isolasi agarosa meliputi cetyl piridinium klorida p.a., iota karaginan refine hasil ekstraksi dari Eucheuma spinosum, kaporit, asam asetat 3\% teknis, celite dan isopropanol (IPA) teknis. Selain itu digunakan pula bahan-bahan kimia untuk analisis agarosa, antara lain: akuades, $\mathrm{HCl}, \mathrm{BaCl}_{2}$ p.a., fruktosa p a., asam benzoat p.a., resorcinol dan acetaldehyde acetal.

Pada penelitian ini agarosa diisolasi dari filtrat agar-agar dengan menggunakan cetyl piridinium klorida. Perlakuan yang diberikan adalah perbedaan jumlah iota karaginan yang ditambahkan pada proses tersebut $(0 \% ; 0,5 \% ; 1 \% ; 1,5 \%)$ dari bobot rumput laut kering. Proses ekstraksi agarosa dari rumput laut mengacu pada penelitian Santos dan Doty (1983) dengan melakukan modifikasi pada penambahan iota karaginan terhadap filtrat hasil ekstraksi agarnya. Bahan baku rumput laut Gracilaria chilensis yang telah kering dipucatkan dengan merendam dalam larutan kaporit $\left(\mathrm{CaOCl}_{3}\right)$ 0,25\% selama 90 menit. Selanjutnya dilakukan pencucian berulang-ulang sampai pH netral. Kemudian dilakukan praperlakuan asam dengan merendam dalam asam asetat 3\% selama 1 jam dan dicuci sampai $\mathrm{pH}$ netral. Selanjutnya rumput laut diekstrak dengan air sebanyak 20 kali bobot rumput laut kering pada $\mathrm{pH} 6-7$ dengan suhu $85^{\circ} \mathrm{C}$ selama 3 jam. Filtrat kemudian disaring dengan kain saring Terhadap filtrat ini kemudian ditambahkan cetyl piridinium klorida $5 \%$, dan iota karaginan yang divariasi sebanyak $0 ; 0,5,1$ dan $1,5 \%$ dari bobot rumput laut kering. Penggunaan cetyl piridinium klorida sebesar $5 \%$ dari bobot rumput laut kering dalam penelitian ini dengan asumsi sudah berlebih untuk mengikat semua agaropektin dalam agar, karena kadar sulfat agar dari hasil penelitian pendahuluan hanya sebesar 1,77 $2,55 \%$. Perlakuan variasi kadar iota karaginan diharapkan dapat mendapatkan jumlah penambahan yang optimal dalam proses, dimana penambahan karaginan pada metode ini ditujukan untuk memperbesar ukuran endapan sulfat yang terbentuk sehingga memudahkan dalam proses pemisahannya. Setelah itu ditambahkan celite $10 \%$ dari volume filtrat (b/v) sambil diaduk selama 15 menit, dan dilakukan penyaringan filtrat menggunakan plankton net ukuran 150 mesh dengan bantuan pompa vakum. Proses selanjutnya adalah pencetakan dengan menggunakan pan pencetak dan dilanjutkan dengan pembekuan pada suhu $-10^{\circ} \mathrm{C}$ selama 24 jam. Produk beku kemudian dilelehkan dengan mengalirkan air, dan selanjutnya dilakukan perendaman dalam IPA teknis selama 1 jam. Serat agarosa kemudian dipisahkan, diperas dan direndam dalam IPA lagi selama 15 menit untuk memperbesar penyerapan air sebelum dikeringkan. Produk kemudian dikeringkan dalam oven sampai kering ( \pm 24 jam) pada suhu $50-55^{\circ} \mathrm{C}$ selanjutnya digiling menjadi bubuk agarosa dengan ukuran 60 mesh

Parameter yang diamati meliputi rendemen agarosa, kadar air (AOAC, 1980), clean anhydrous weed (CAW) (Santos dan Doty, 1983), kadar sulfat (Anonim, 1991), kadar 3,6-anhidro-galaktosa (Stanley, 1966), kekuatan gel pada $1 \%$ larutan agar (curd meter method), suhu pembentukan get: (Stanley, 1966) dan suhu pelelehan gel (Stanley, 1966).

Rancangan percobaan yang digunakan adalah rancangan acak lengkap faktor tunggal dengan 5 perlakuan dan 3 ulangan. Selanjutnya dilakukan analisis varian, dan bila hasilnya berbeda nyata dilanjutkan dengan uji perbandingan berganda beda nyata jujur (BNJ) untuk melihat perbedaan antar perlakuan (Gomez dan Gomez, 1995).

\section{HASIL DAN BAHASAN}

\section{Rendemen}

Rendemen agarosa pada penelitian ini dihitung berdasar bobot rumput laut kering. Nilai rata-rata rendemen yang diperoleh pada penelitian ini berkisar antara $11,88 \%$ sampai $12,89 \%$. Nilai rata-rata 
rendemen agarosa untuk masing-masing perlakuan dapat dilihat pada Gambar 1.

Hasil analisis ragam $(\alpha=0,05)$ menunjukkan bahwa keempat perlakuan penambahan iota karaginan dengan konsentrasi yang berbeda-beda tidak memberikan pengaruh yang berbeda nyata terhadap rendemen agarosa. Hal ini kemungkinan disebabkan karena proses ekstraksi agar dan jenis rumput laut nyata terhadap kadar air agarosa. Hal ini disebabkan karena semua bahan dikeringkan dengan menggunakan alat pengering (oven dengan suhu antara $50^{\circ} \mathrm{C}$ sampai $55^{\circ} \mathrm{C}$ ) dan waktu pengeringan yang sama (sekitar 24 jam) serta ketebalan bahan yang relatif sama (berupa serat tipis sekitar $1 \mathrm{~mm}$ ). Nilai rata-rata kadar air pada penilitian ini dapat dilihat pada Gambar 2.

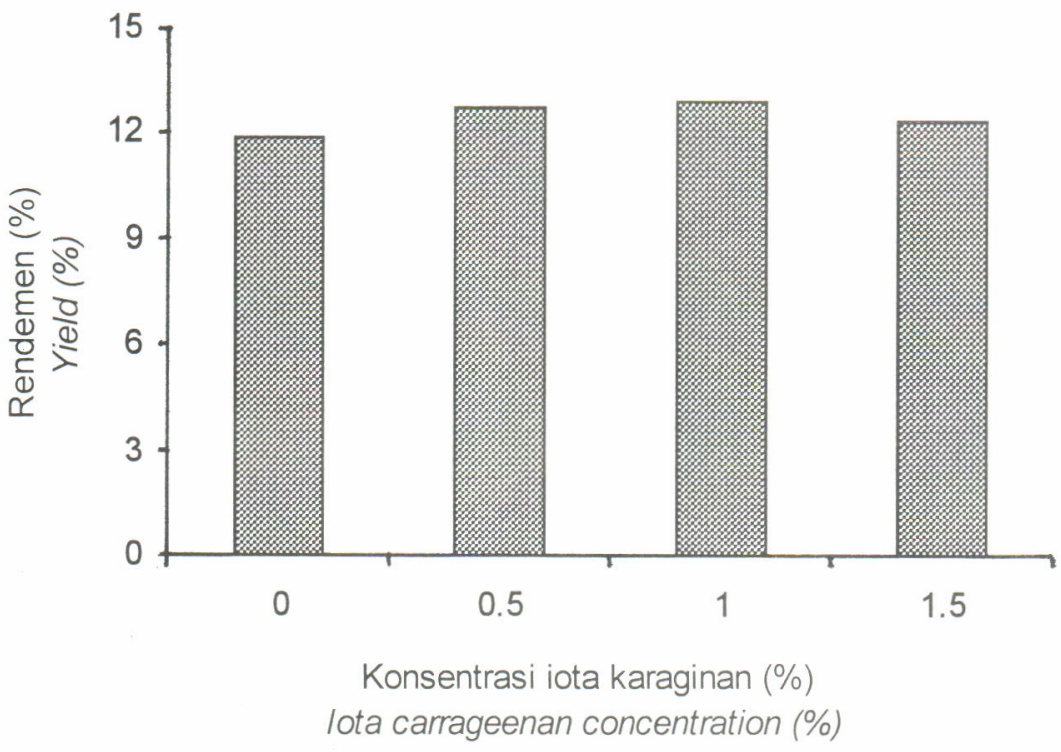

Gambar 1. Pengaruh konsentrasi iota karaginan terhadap rendemen agarosa

Figure 1. The effect of iota carrageenan concentration on the yield of agarose

yang digunakan sama dan penambahan iota karaginan pada pemurnian agarosa memang tidak memberikan pengaruh yang nyata terhadap rendemen agarosanya. Menurut Chapman dan Chapman (1980) faktor yang mempengaruhi rendemen agarosa adalah jenis dari rumput laut itu sendiri serta teknik isolasinya.

Nilai rendemen yang dihasilkan pada penelitian ini hampir sama dengan hasil yang diperoleh Santos dan Doty (1983) yaitu sekitar 13\%. Adanya sedikit perbedaan rendemen dari hasil penelitian Santos dan Doty (1983) diduga disebabkan karena perbedaan jenis dan tingkat kekeringan rumput laut yang digunakan.

\section{Kadar Air}

Nilai rata-rata kadar air pada penelitian ini berkisar antara $10,35 \%$ sampai $11,33 \%$. Kadar air tersebut masih memenuhi ketentuan SII yang mensyaratkan kadar air maksimal $15 \%$ sampai $24 \%$. Analisis ragam $(\alpha=0,05)$ menunjukkan bahwa masing-masing perlakuan tidak memberikan pengaruh yang berbeda

\section{Kadar Sulfat}

Kandungan sulfat dalam agarosa menunjukkan adanya agaropektin yang masih tersisa dalam agarosa setelah proses pemisahan. Nilai rata-rata kadar sulfat berkisar antara $0,57 \%$ sampai $0,81 \%$. Hasil analisis ragam $(\alpha=0,05)$ menunjukkan bahwa perbedaan konsentrasi iota karaginan memberikan pengaruh yang berbeda nyata terhadap kandungan sulfat dari agarosa. Hasil uji lanjut beda nyata jujur menunjukkan bahwa perlakuan tanpa penambahan iota karaginan berbeda nyata dengan perlakuan penambahan iota karaginan $1 \%$ dan $1,5 \%$ tetapi tidak berbeda nyata dengan penambahan $0,5 \%$. Penambahan iota karaginan menyebabkan proses pengendapan agaropektin lebih efektif dibandingkan tanpa menggunakan iota karaginan. Hal ini diduga bahwa molekul agaropektin yang sudah terikat oleh cetyl piridinium klorida akan membentuk koloid yang berukuran besar dengan penambahan iota karaginan, sehingga akan lebih mudah terendapkan dan mudah dipisahkan melalui proses penyaringan. Dengan demikian molekul agaropektin akan lebih banyak diendapkan dan 
dipisahkan (Santos dan Doty, 1983). Hal ini dapat dilihat dari nilai rata-rata kadar sulfat yang diperoleh, yaitu pada proses tanpa penambahan iota karaginan diperoleh kadar sulfat sebesar $0,81 \%$ lebih besar dibandingkan dengan perlakuan penambahan iota karaginan $0,5 \%, 1 \%$ dan $1,5 \%$ yang menghasilkan kadar sulfat lebih kecil yaitu berturut-turut sebesar $0,73 \%, 0,59 \%$ dan $0,57 \%$. Hal ini berarti bahwa penambahan iota karaginan akan mengendapkan lebih banyak agaropektin sehingga kadar sulfatnya lebih
Chapman, 1980). Pada penelitian ini diperoleh kadar sulfat terkecil sebesar $0,57 \%$. Hasil ini masih dapat diterima karena menurut Guiseley dan Renn (1975), agarosa umumnya memiliki kandungan sulfat kurang dari $0,7 \%$. Meskipun demikian, kadar sulfat agarosa yang ada di pasaran umumnya memiliki kandungan sulfat 0,1-0,35\% (Sigma-Aldrich, 2002-2003). Masih tingginya kadar sulfat yang terdapat dalam agarosa mengakibatkan masih rendahnya kekuatan gel yang diperoleh pada penelitian ini.

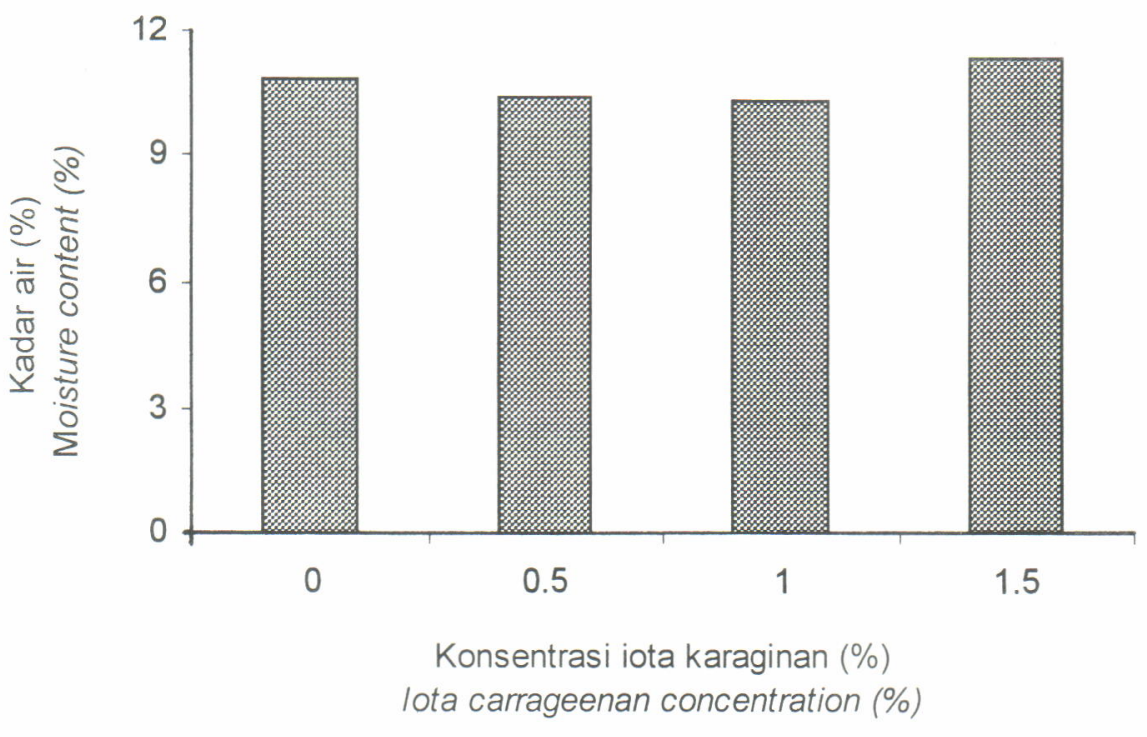

Gambar 2. Pengaruh konsentrasi iota karaginan terhadap kadar air agarosa

Figure 2. The effect of iota carageenan concentration on the moisture of agarose

kecil dibandingkan tanpa menggunakan iota karaginan. Jika dibandingkan dengan nilai kadar sulfat agarosa yang dijual di pasaran internasional, maka kadar sulfat yang diperoleh pada penelitian ini masih lebih tinggi. Tetapi jika dibandingkan dengan kadar sulfat agar-agarnya yang mencapai $1,77-2,55 \%$, ternyata metode ekstraksi ini dapat menurunkan kadar sulfat sehingga tinggal $0,57-0,81 \%$ dalam agarosa. Nilai rata-rata kadar sulfat untuk masing-masing perlakuan dapat dilihat pada Gambar 3.

Pada Gambar 3 terlihat bahwa semakin banyak iota karaginan yang ditambahkan maka kandungan sulfat agarosanya semakin rendah. Hal ini terjadi karena semakin besar endapan sulfat yang terbentuk atau yang terikat maka semakin mudah pula untuk dipisahkan (disaring), sehingga kadar sulfat yang dihasilkan semakin kecil. Kadar sulfat akan mempengaruhi kekuatan gel dari agarosa. Semakin tinggi kandungan ester sulfat, maka kekuatan gel yang terbentuk akan semakin rendah (Chapman dan

\section{Kadar 3,6-anhidro-galaktosa}

Nilai rata-rata kadar 3,6-anhidro-galaktosa pada penelitian ini berkisar antara $36,48 \%$ sampai $38,44 \%$, dan nilai rata-rata untuk masing-masing perlakuan dapat dilihat pada Gambar 4

Meskipun dari grafik terlihat bahwa semakin banyak konsentrasi iota karaginan yang ditambahkan menyebabkan nilai rata-rata kadar 3,6-anhidrogalaktosa yang cenderung semakin besar, akan tetapi hasil analisis ragam menunjukkan bahwa perlakuan tersebut tidak memberikan pengaruh yang berbeda nyata. Kadar 3,6-anhidro-galaktosa dipengaruhi oleh jenis, asal rumput laut dan umur panen rumput laut, serta penanganan yang dilakukan selama proses pengolahan (Purnawati, 1992).

Kadar 3,6-anhidro-galaktosa biasanya berbanding lurus dengan kekuatan gel dari agarosa dan berbanding terbalik dengan kandungan sulfat yang dimiliki agarosa. Dalam penelitian ini kekuatan gel 


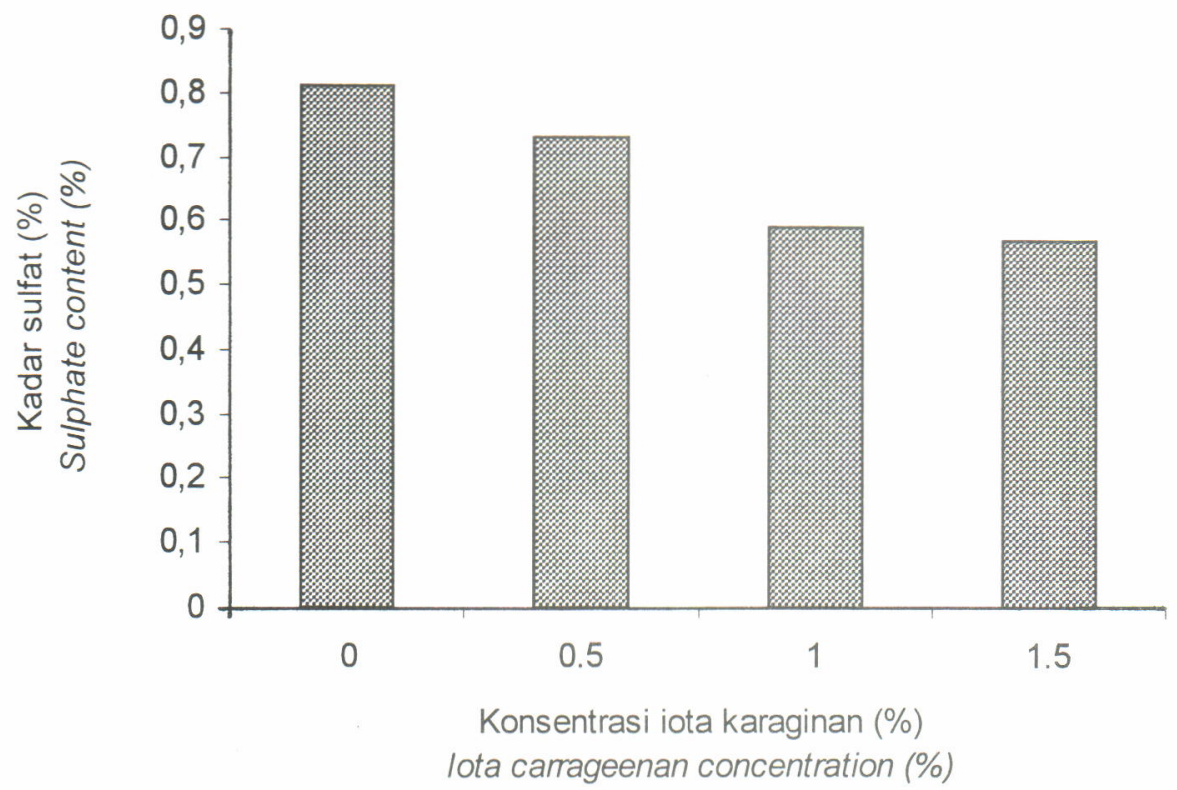

Gambar 3. Pengaruh konsentrasi iota karaginan terhadap kadar sulfat agarosa Figure 3. The effect of iota carageenan concentration on the sulphate content of agarose

agarosa yang dihasilkan lebih ditentukan oleh perbedaan kandungan sulfat (agaropektin) dalam agarosa karena kadar 3,6-anhidro-galaktosa dalam penelitian ini tidak berbeda nyata. Hasil penelitian Izumi (1971), menyatakan bahwa penurunan kadar 3,6-anhidro-galaktosa selalu disertai dengan penurunan kandungan grup 6-0-metil dan peningkatan residu sulfat.

Kadar 3,6-anhidro-galaktosa pada penelitian ini masih tergolong rendah, yang mengakibatkan kekuatan gel agarosa yang dihasilkannya rendah. Peningkatan kekuatan gel sangat berkaitan dengan

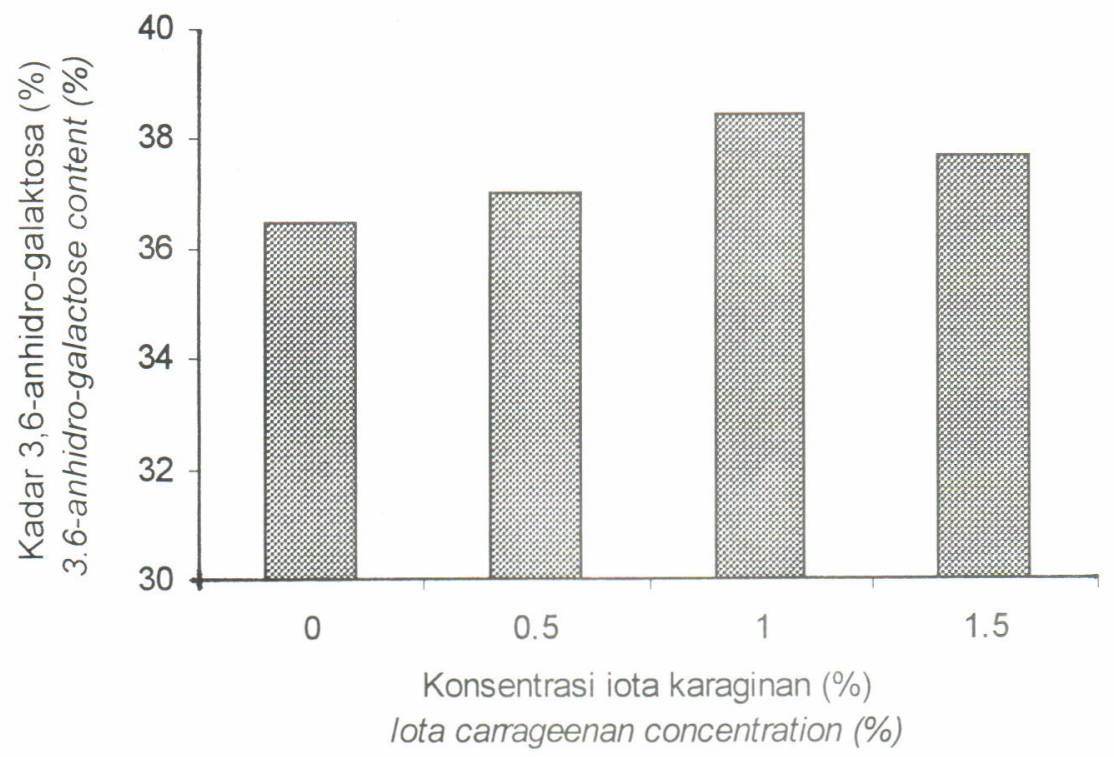

Gambar 4. Pengaruh konsentrasi iota karaginan terhadap kadar 3,6-anhidro-galaktosa agarosa Figure 4. The effect of iota carageenan concentration on 3.6-anhidro-galactose content of agarose 
jumlah 3,6-anhidro-galaktosa dan sulfat yang terkandung dalam agarosa (Guiseley dan Renn, 1975).

\section{Kekuatan Gel Agarosa}

Kekuatan gel agarosa dinyatakan sebagai breaking force yang didefinisikan sebagai beban maksimum yang dibutuhkan untuk memecah matriks polimer pada daerah yang terbebani. Nilai rata-rata kekuatan gel untuk masing-masing perlakuan yang diperoleh pada penelitian ini dapat dilihat pada Gambar 5.

Hasil analisis ragam $(\alpha=0,05)$ menunjukkan bahwa perlakuan penambahan iota karaginan memberikan pengaruh yang nyata terhadap kekuatan gel dari agarosa. Hasil uji lanjut beda nyata jujur, menunjukkan bahwa perlakuan penambahan iota karaginan $0,5 \%$, $1 \%$ dan $1,5 \%$ berbeda nyata dengan perlakuan tanpa penambahan iota karaginan, tetapi perlakuan penambahan $0,5 \%, 1 \%$ dan $1,5 \%$ di antara ketiganya tidak memberikan pengaruh yang berbeda nyata kekuatan gel yang dihasilkan pada penelitian ini tertinggi mencapai $188,14 \mathrm{~g} / \mathrm{cm}^{2}$ yaitu pada penambahan iota karaginan $1 \%$, dimana nilai ini masih terlalu kecil untuk ukuran agarosa karena umumnya agarosa memiliki kekuatan gel $\geq 500 \mathrm{~g} /$ $\mathrm{cm}^{2}$. Karakteristik pembentukan gel disebabkan oleh tiga buah atom hidrogen pada 3,6-anhidro-L-galaktosa yang memaksa molekul-molekul untuk membentuk struktur heliks, dan interaksi dari struktur heliks ini akan membentuk gel. Dengan demikian apabila kadar 3,6-anhidro-L-galaktosa sedikit maka struktur heliks yang akan terbentuk juga sedikit dan pembentukan gel juga sulit terjadi (Glicksman, 1983).

Selain itu struktur heliks tidak akan terbentuk bila semua galaktosa dalam ekstrak rumput laut terdapat dalam bentuk galaktosa-6-sulfat. Terdapatnya Lgalaktosa-6-sulfat dalam jumlah besar akan menyebabkan penurunan kekuatan gel, karena struktur heliks yang terbentuk hanya sedikit (Glicksman, 1983). Kemungkinan lain yang

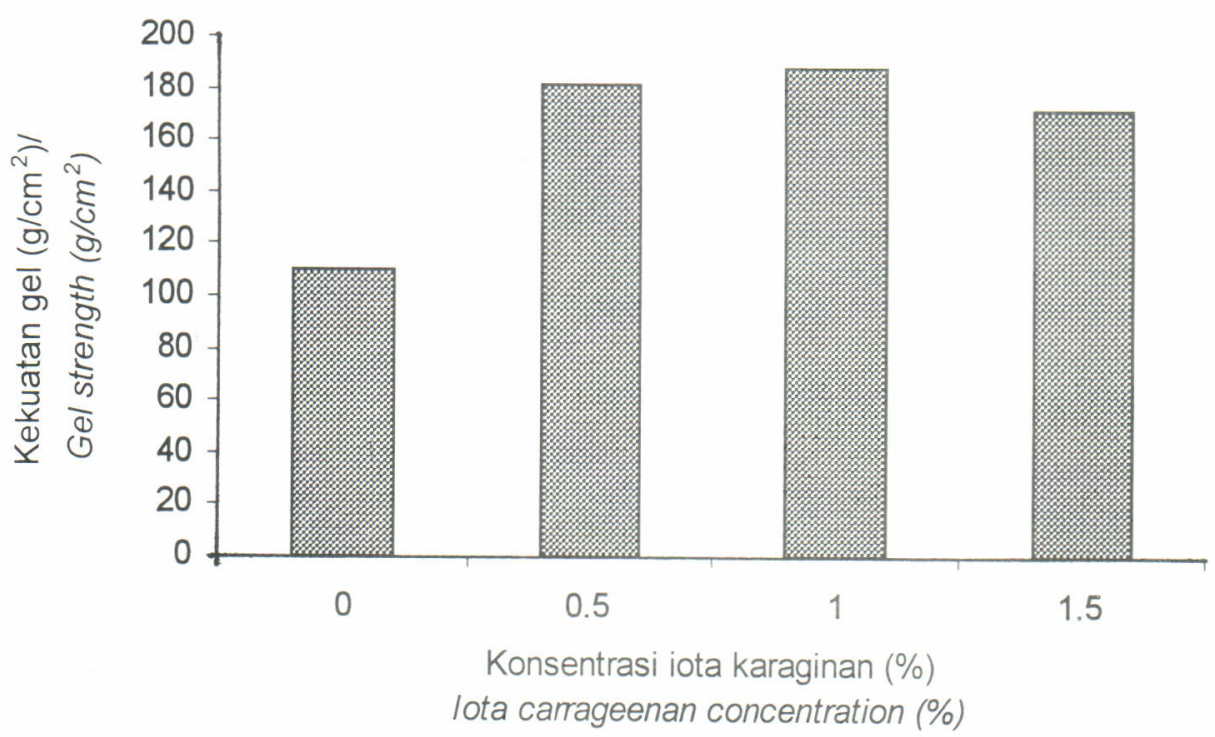

Gambar 5. Pengaruh konsentrasi iota karaginan terhadap kekuatan gel agarosa Figure 5. The effect of iota carageenan concentration on the gel strength of agarose

terhadap kekuatan gel agarosa. Perlakuan tanpa penambahan iota karaginan menghasilkan nilai ratarata kekuatan gel yang rendah diduga karena penambahan iota karaginan menyebabkan proses pengendapan agaropektin lebih efektif dibandingkan dengan tanpa menggunakan iota karaginan.

Semakin banyak agaropektin yang dapat dipisahkan pada proses isolasi agarosa, maka kekuatan gel yang dimiliki oleh agarosa tersebut akan semakin meningkat (Glicksman, 983). Nilai rata-rata menyebabkan rendahnya kekuatan gel adalah terjadinya hidrolisis asam, sebab pada proses ekstraksi sebelumnya dilakukan pra perlakuan asam pada rumput laut yang akan diekstrak.

Hidrolisis asam terhadap agarosa akan menghasilkan disakarida agarobiosa (4-0-b-Dgalaktosa 3,6-anhidro-L-galaktosa). Disakarida yang terbentuk tersebut tidak berperan sama sekali terhadap pembentukan gel karena merupakan suatu karbohidrat berantai pendek, dan dapat larut dalam asam cuka 
(Chapman dan Chapman, 1980). Keasaman sangat mempengaruhi kekuatan ikatan gel rantai galaktosa. Semakin rendah $\mathrm{pH}$ atau semakin asam, maka kekuatan gelnya akan semakin rendah. Selain itu, jenis rumput laut dan metode ekstraksi juga merupakan faktor-faktor yang dapat mempengaruhi kekuatan gel agarosa (Glicksman, 1983)

\section{Suhu Pembentukan Gel}

Suhu pembentukan gel merupakan suhu dimana larutan agarosa yang telah dididihkan mulai membentuk gel kembali. Nilai rata-rata suhu pembentukan gel agarosa pada penelitian ini berkisar antara $33,17^{\circ} \mathrm{C}$ sampai $34,83^{\circ} \mathrm{C}$, dan nilai rata-rata suhu pembentukan gel dapat dilihat pada Gambar 6 .

Larutan agar-agar encer 1,5\% dapat membentuk gel pada suhu $32^{\circ} \mathrm{C}$ sampai $39^{\circ} \mathrm{C}$ (Furia, 1975). Hasil analisis ragam $(\alpha=0,05)$ menunjukkan bahwa masingmasing perlakuan tidak memberikan pengaruh yang nyata terhadap suhu pembentukan gel dari agarosa yang dihasilkan. Hal ini terjadi karena kadar 3,6anhidro-galaktosa yang diperoleh pada penelitian ini menunjukkan hasil tidak berbeda nyata atau mempunyai nilai yang hampir sama. Hasil penelitian Purnawati (1992) menjelaskan bahwa suhu pembentukan gel erat kaitannya dengan kadar 3,6anhidro-L-galaktosa dan kadar sulfat. Adanya 3,6anhidro-L-galaktosa dalam molekul agar-agar menyebabkan sifat beraturan dalam rantai polimer bertambah dan sebagai akibatnya akan mempertinggi potensi pembentukan heliks rangkapnya. Dengan demikian suhu pembentukan gel lebih cepat tercapai.

Hal lain yang mempengaruhi suhu pembentukan gel adalah keberadaan senyawa metoksil yang terdapat dalam agarosa. Berdasarkan penelitian Guiseley (1970), titik pembentukan gel berhubungan dengan kadar metoksil yang terkandung dalam agarosa.

Peningkatan kadar metoksil pada agarosa akan meningkatkan titik pembentukan gel. Metoksil dalam agarosa berada dalam bentuk monometil galaktosa, pada jenis rumput laut Gracilaria verrucosa monometil galaktosa berada dalam bentuk 6-0-metil-galaktosa. Keberadaan senyawa 6-0-metil-D-galaktosa ini mempengaruhi suhu yang diperlukan untuk pembentukan gel. Semakin tinggi kandungan senyawa tersebut, titik pembentukan gel agarosa akan semakin tinggi pula.

\section{Suhu Pelelehan Gel}

Nilai rata-rata suhu pelelehan gel untuk masingmasing perlakuan berkisar antara $81,83^{\circ} \mathrm{C}$ sampai $85,83^{\circ} \mathrm{C}$ seperti terlihat pada Gambar 7. Hasil analisis ragam $(\alpha=0,05)$ memperlihatkan bahwa masingmasing perlakuan tidak memberikan pengaruh yang berbeda nyata terhadap suhu pelelehan gel agarosa. Hal ini kemungkinan disebabkan karena agarosa yang dihasilkan untuk masing-masing perlakuan

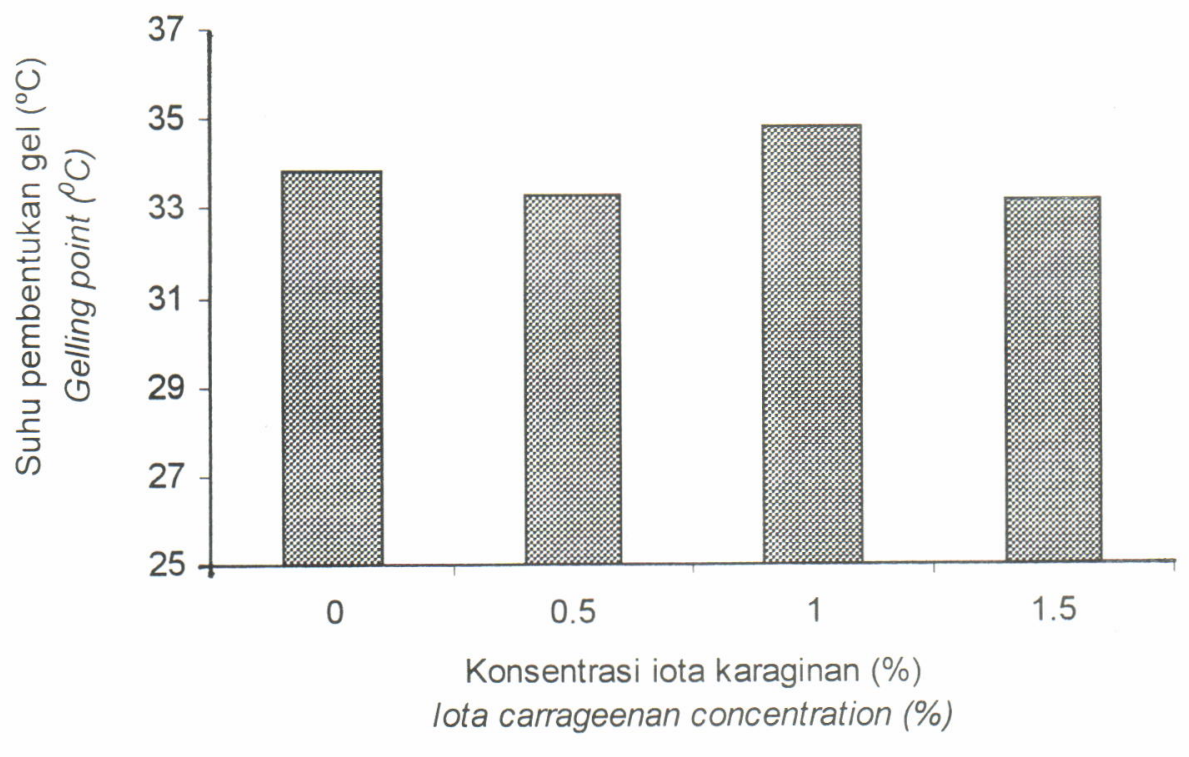

Gambar 6. Pengaruh konsentrasi iota karaginan terhadap suhu pembentukan gel agarosa Figure 6 . The effect of iota carageenan concentration on the gelling point of agarose 


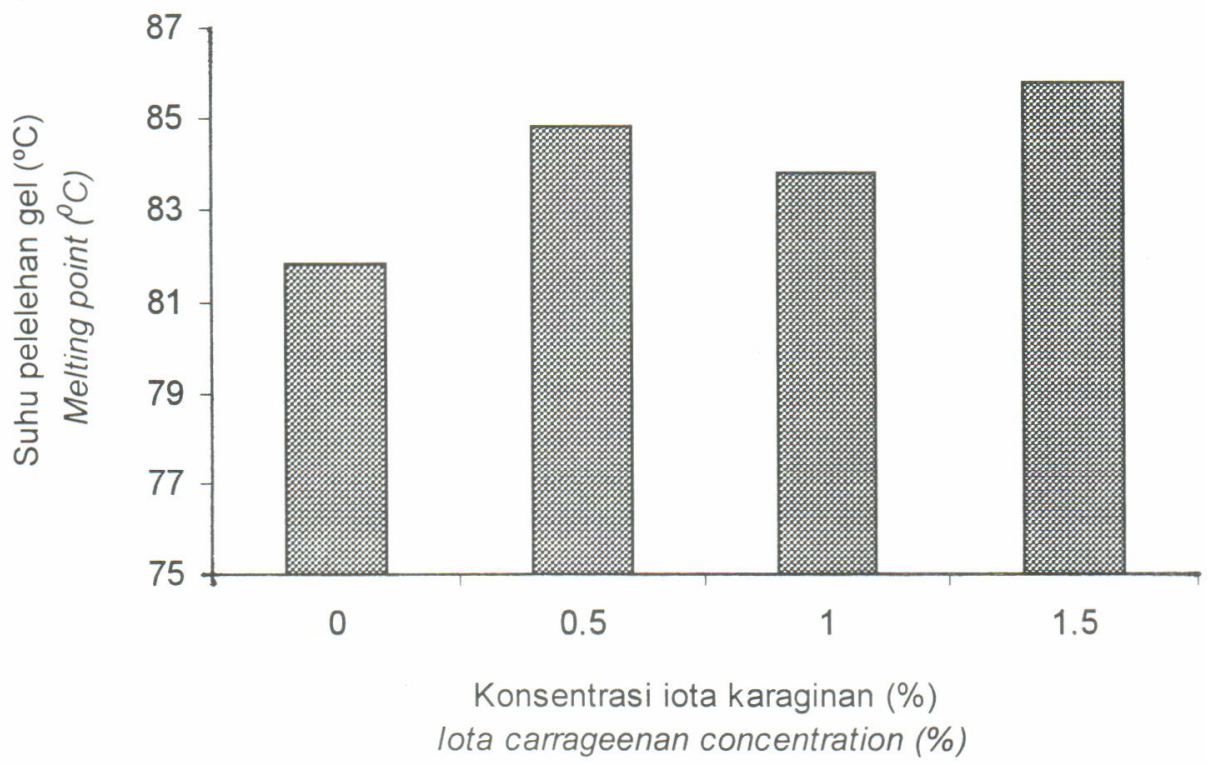

Gambar 7. Pengaruh konsentrasi iota karaginan terhadap suhu pelelehan gel agarosa Figure 7. The effect of iota carageenan concentration on the melting point of agarose

mempunyai bobot molekul yang hampir sama dan kandungan 3,6-anhidro-galaktosanya juga hampir sama. Menurut Glicksman (1983), suhu pelelehan gel dipengaruhi oleh bobot molekul dan ikatan hidrogen yang terdapat dalam bahan tersebut. Bobot molekul yang tinggi akan menyebabkan temperatur leleh semakin tinggi. Ikatan hidrogen akan terjadi antara oksigen pada atom $\mathrm{C}$ kedua dari suatu rantai polimer polisakarida dengan oksigen pada atom $\mathrm{C}$ kedua dari suatu rantai polimer polisakarida yang lainnya dan akibat adanya ikatan hidrogen ini akan terbentuk jaringan polimer yang kompleks. Untuk mengurai jaringan tersebut dibutuhkan energi yang tinggi sehingga suhu pelelehan gelnya akan semakin tinggi.

Suhu pelelehan gel bukan merupakan faktor yang langsung mencerminkan kualitas agarosa, karena pada kenyataannya agarosa yang ada di pasaran sebagian besar tidak mencantumkan spesifikasi suhu pelelehan gelnya. Meskipun demikian rentang suhu yang tinggi antara suhu pembentukan gel dan suhu pelelehan gel biasanya lebih dikehendaki karena akan memudahkan dalam penggunaannya di lapangan.

\section{KESIMPULAN}

Berdasarkan hasil penelitian, penambahan iota karaginan pada proses ekstraksi agarosa dengan menggunakan cetyl piridinium klorida pada konsentrasi $0 \%$ sampai dengan $1,5 \%$ memberikan pengaruh terhadap sifat fisika dan kimia agarosa yang dihasilkan. Perlakuan tersebut hanya memberikan pengaruh nyata terhadap kadar sulfat dan kekuatan gel, sedangkan terhadap rendemen, kadar air, kadar 3,6-anhidro-galaktosa, suhu pembentukan gel dan suhu pelelehan gel agarosa tidak berpengaruh nyata.

Berdasarkan hasil analisis kadar sulfat dan kekuatan gel dari agarosa yang dihasilkan, diperoleh kesimpulan bahwa penggunaan cetyl piridinium klorida dalam ekstraksi agarosa menghasilkan produk agarosa terbaik pada penambahan iota karaginan dengan konsentrasi 1\%. Pada perlakuan ini diperoleh kadar sulfat agarosa yang cukup rendah yaitu sebesar $0,59 \%$ dan kekuatan gel sebesar $188,14 \mathrm{~g} / \mathrm{cm}^{2}$ Perlakuan penambahan iota karaginan dengan konsentrasi $1,5 \%$ menghasilkan kadar sulfat dan kekuatan gel yang tidak berbeda nyata dengan perlakuan konsentrasi iota karaginan 1\%, sehingga secara ekonomis penggunaan iota karaginan $1 \%$ lebih efisien. Hasil penelitian ini belum dapat menghasilkan produk agarosa komersial.

\section{SARAN}

Dibandingkan dengan standar komersial, kekuatan gel agarosa yang dihasilkan masih rendah sehingga perlu dilakukan penelitian lebih lanjut dengan menggunakan bahan baku rumput laut jenis lain yang memiliki kualitas yang lebih baik, karena kualitas agarosa yang dihasilkan selain ditentukan oleh cara ekstraksinya juga sangat ditentukan oleh kualitas 
bahan baku yang dipergunakan. Selain itu perlu dilakukan penelitian cara penghilangan sulfat secara enzimatis.

\section{DAFTAR PUSTAKA}

Anonim, 1991. Prosiding Temu Karya IImiah Teknologi Pasca Panen Rumput Laut, 11-12 Maret. Buku II. Pusat Penelitian dan Pengembangan Perikanan. Departemen Pertanian. Jakarta. 172 pp.

AOAC. 1980. Official Methods of Analysis of the Association of Official Analytical Chemists, $13^{\text {th }}$ ed. AOAC, Inc. Arlington. Virginia 1018 pp.

Chapman, V. J. and Chapman, D. J. 1980. Seaweed and Their Uses. Chapman and Hall. London. 333 pp.

Furia, T. E. 1975. Handbook of Food Additives: Gums. $2^{\text {nd }}$ ed. CRC Press, Inc, Boca-Raton. Florida. p. 295359.

Glicksman, M. 1983. Food Hydrocolloids. Vol. II. CRC Press, Inc. Boca Raton. Florida. 199 pp.

Gomez, K. A dan Gomez, A. A. 1995 Prosedur Statistik Untuk Penelitian Pertanian. Terjemahan oleh Sjamsuddin, E. dan Baharsjah, J.S. UI Press. 697 $p p$

Guisseley, K. B. 1968. Seaweed colloids. In Othmer, K. (ed.). Encyclopedia of Chemical Technology. Volume 17. John Willey and Sons, Inc., USA. p. 763-784.

Guisseley, K. B. 1970. The relationship between methoxyl content and gelling temperature of agarose. Carbohydr. Res. 13:247-256.
Guisseley, K. B. and Renn, D. W. 1975. Agarose. Marine Colloids Division, FMC Corporation. Rocland, Maine. $34 \mathrm{pp}$.

Hjerten, S. 1962. A new method for preparation of agarose for gel electrophoresis. J. Biochem. Biophysic. Acta. $62: 445-449$.

Izumi, K. 1971. Chemical heterogenity of the agar from Gracilaria verrucosa. J. Biochem. $72: 135-140$.

Moirano, A. L. 1977. Sulfated seaweed polysacharides. In Food Colloids. The AVI Publishing Company, Inc. Wesport. Connecticut. $588 \mathrm{pp}$

Purnawati, D. W. 1992. Pengaruh Perbandingan Rumput Laut Gracilaria verrucosa dan Gelidium rigidium terhadap Mutu Agar-agar Kertas. Skripsi. Fakultas Teknologi Pertanian. IPB. Bogor. 84 pp.

Santos, G. A. and Doty, M. S. 1983. Agarose from Gracilaria cylindrica. Botanica Marina Vol. XXVI. pp. 31-34.

Selby, H. H. and Wyne, W. H. 1973. Agar. In Whistler, R.L. dan Be Miller, J.M. (eds.). Industrial Gums. Academic Press. New York. 807 pp.

Sigma-Aldrich. 2002-2003. Biochemicals and Reagents for Life Science Research. 2872 pp.

Stanley, N. F. 1966. Standard Practice Instructions C 19 Marine Colloid, Inc. Rocland, Maine. 4 pp.

Winarno, F. G. 1984. Kimia Pangan dan Gizi. PT. Gramedia Jakarta. p. 66-74. 